\title{
Educational innovation and university academics: the challenges of incorporating change into teaching and management practice
}

\section{La innovación educativa y los académicos universitarios: los retos para incorporar el cambio a la práctica formativa y de gestión}

\author{
VERDÍN-ZEA, Aldo A.†*, ABUNDIS-DE LEÓN, Felipe and GONZALEZ-BASILIO, Sofía de Jesús \\ Universidad Autónoma de Nayarit \\ Universidad Autónoma de Nuevo León \\ ID $1^{\text {st }}$ Author: Aldo A., Verdin-Zea \\ ID $1^{\text {st }}$ Coauthor: Felipe, Abundis-De León \\ ID $2^{\text {nd }}$ Coauthor: Sofía de Jesús, Gonzalez-Basilio
}

DOI: $10.35429 / J H R T .2020 .17 .6 .1 .9$

Received January 21, 2020; Accepted June 29, 2020

\begin{abstract}
The processes of educational and curricular innovation have been presented in recent decades within the Higher Education Institutions in a remarkable way by the emergence of new policies by the governments in charge, as well as by the various social movements that have promoted improvements in the processes of student learning. However, the accelerated work that has been done to incorporate change into education systems has left two issues unresolved, on the one hand, the careful and in-depth analysis of the concept of innovation and on the other, the way in which academics incorporate change into practice both in classroom and in academic management. The purpose of this research is to make progress in these two aspects, and to do so, it addresses innovation from the perspective of globalization and identifies academics as factors of change.
\end{abstract}

Innovation, Academics, Incorporation, Learning Practice

\begin{abstract}
Resumen
Los procesos de innovación educativa y curricular se han presentado en las últimas décadas dentro de las Instituciones de Educación Superior (IES) de una manera sorprendente, tanto por el surgimiento de nuevas políticas por parte de los gobiernos en turno, como por los diversos movimientos sociales que han impulsado cambios en los procesos de formación de los estudiantes. Sin embargo, el trabajo vertiginoso que se ha realizado para incorporar el cambio en los sistemas educativos ha dejado dos temas pendientes, por un lado, el análisis cuidadoso y profundo del concepto de innovación y por otro, la forma en cómo los académicos incorporan el cambio a la práctica, tanto en los espacios áulicos como en los procesos de gestión académica. El presente estudio tiene como propósito avanzar en esos dos aspectos y para ello se aborda la innovación desde líneas vinculadas a procesos globales y se trabaja con los académicos como sujetos posibilitadores del cambio.
\end{abstract}

Innovación, Académicos, Incorporación, Práctica Formativa

Citation: VERDÍN-ZEA, Aldo A., ABUNDIS-DE LEÓN, Felipe and GONZALEZ-BASILIO, Sofía de Jesús. Educational innovation and university academics: the challenges of incorporating change into teaching and management practice. Journal of Human Resources Training. 2020. 6-17: 1-9.

\footnotetext{
* Correspondence to Author (aldoverdin@ @otmail.com)

$\dagger$ Researcher contributing as first autor
} 


\section{Introduction}

In the field of education, the term innovation is a new concept, which is generally presented in association with a modernizing discourse from which various policies and programs related to educational reforms and changes are structured (Gros and Lara 2009, Orozco 2010, Díaz Villa 2014).

As it is a concept that appears linked to the policies of change and modernization of education, it is used in various ways, in heterogeneous contexts (basic education, upper secondary and higher education) and with meanings associated with specific spaces, where in the implications they have regarding the representation and practices of the agents of the different fields of education are rarely analyzed.

The innovation in the curriculum of the universities responds to a set of policies at the international and national level, which dictate and guide the application of various approaches with the aim of improving. Since the 1980s, Latin American universities have undertaken a series of changes in their training processes, which have been the result of macro trends associated with a set of curricular policies at the international and Latin American level (Díaz Barriga, 2013); as well as the incorporation of strategic trends or micro-trends (Díaz Villa, 2011) that are interpretations of the institutions associated with the context and that have an organizational type reading that allows them to be concretized.

It is then that the Autonomous University of Nayarit (UAN) is no stranger to all this hustle and bustle of curricular innovations that HEIs face, and that is why in 2010-2011, an entire updating process was proposed at the institutional level of the plans and programs of studies at the bachelor's level, which meant a series of challenges and transformation within it, therefore the interest of the research that is carried out, focuses on working with the academics that faced the process of curricular updating and various manifestations of educational innovation.

\section{Educational-curricular innovation and the public university}

Regarding the positioning of Latin American universities to assume the changes, Bruner (2005) argues that universities since their origin have been considered in the public sphere for being the institutions that offer higher education and have recognition of their social character. From this author's perspective, universities have upheld and legitimized the right to train professionals and grant degrees.

The university's ability to structure proposals whose scope affects the order of the social structure, is one of the main elements to focus attention on its activity and the processes that take place within it. One of these processes refers to the construction of university curricular projects, which, in a broad sense, are political projects (De Alba, 1991), where the formation of subjects represents the synthesis of cultural elements that hegemonic groups determine for a professional practice.

The ability of universities to define their curricular projects is indisputably associated with their autonomy. This is obtained through various mechanisms of struggle and negotiation that, upon consolidation according to Brunner (2005, p.32), acquire "the right to act as an institutional body vis-à-vis the external world, to control the recruitment of its members - teachers and students - and to dictate its own internal regulations and apply them jurisdictionally".

In Mexico, educational reforms are not exempt from the political and economic pressures that make HEIs propose processes of "change with absence" (De Alba, 1991), reflection on the social conditions that determine the public university and, even more so., without an analysis of the institutional conditions and the educational system that define or not the viability of the reforms that are undertaken.

Acosta (2000) and Furlan (2012) affirm that the set of policies that at Latin American level had a strong impact on the curricular reform processes in the mid and late 1990s, in the Mexican context also had their manifestations, which from the The level of public and educational policy at the national level can be seen in the speeches of the actors that make up the HEI. Hence the need to identify the participation of university academics in curricular innovation processes.

VERDÍN-ZEA, Aldo A., ABUNDIS-DE LEÓN, Felipe and GONZALEZ-BASILIO, Sofía de Jesús. Educational innovation and university academics: the challenges of incorporating change into teaching and management practice. Journal of Human Resources Training. 2020 
In Mexico, in terms of public policies associated with innovation and as part of the macro trends generated internationally, in 2000 the National Association of Universities and Institutions of Higher Education (ANUIES) built a proposal called Higher Education in The 21st century. Strategic lines of development, which sought to materialize the set of changes necessary for a society characterized by the diversity of professional training needs and its centrality in knowledge as an economic good.

According to this document, one of the programs that every university should maintain was that of educational innovation. From this perspective, the ANUIES (2000, p.6) set out as an objective "to improve and, where appropriate, transform the educational models prevailing in HEIs, with a view to achieving better levels of quality, coverage and relevance in higher education".

The proposal for educational innovation as a program appears associated with a series of elements such as the flexibility of classroom time, the transformation of pedagogical practice, the incorporation of technological resources into learning processes, as well as the offer of training options in unconventional modalities (ANUIES, 2000). These proposals are compared with the curricular innovation models described by F. Díaz-Barriga (2005) in the state of Curricular Research in Mexico 2000-2010.

According to Rodríguez (2015), a substantial part of the proposals presented by ANUIES in the 2000 project are still in the construction process by most of the Universities and Institutions of Higher Education. In addition, an absence of evaluation processes of the conditions in which innovative curricular models would be implemented is identified, this implied that the processes for the realization of the discourses in practice did not have a process for monitoring and evaluating their impact.

\section{Context and methodological aspects}

The central part of this work focuses on research carried out at the Autonomous University of Nayarit in light of the curricular innovations that academics have faced.
The UAN is a public educational unit with autonomy to govern itself, classified by the Ministry of Public Education (SEP) as a State Public University. It was established as a university in 1969 and is one of the first state universities in Mexico. It is located in the center of Nayarit, in the municipality of Tepic and has extensions in several municipalities in the state (currently the concept of extensions is being transformed by the Regional Academic Units).

Since its foundation, it has provided care of the upper and upper middle class, maintains an enrollment of 29,717 students and more than 1,400 teachers (UAN, 2019). Approximately 18,063 students are served in higher education, distributed in 68 Academic Programs at the educational levels of Associate Professional and Bachelor and 24 postgraduate (Ibídem), incorporated into six areas of knowledge: Basic Sciences and Engineering, Biological, Agricultural and Fishing Sciences, Sciences of the Health, Arts, Economic and Administrative Sciences and Social Sciences and Humanities.

An important innovation made within the university was to initiate a process of curricular updating in the academic undergraduate programs, which was carried out between 2012 and 2016, managing to modify 29 curricular projects, which to date are in operation. This update is understood as a process of curricular innovation that permeated the design and development of study plans. Among the main innovations in this curricular updating process was the incorporation of integrated professional competences as an achievement unit, a studentcentered training process and different expressions of curricular flexibility. Which were a proposal derived from a study of social relevance carried out at the institutional level and by the current needs of the context.

It is important to clarify that this research does not focus on the study of innovative processes, but on curricular innovation as a process of change in the practices of academics and understand how these have been incorporated into updated study plans at the University. Likewise, the members of the academies of the academic programs are recognized as the main agents of curricular innovation, specifically the academy coordinators, who are responsible for the management of curriculum innovation. 
In this sense, the academy for the University is understood as a "collegiate body made up of members of the academic staff assigned to the University, who carry out a series of activities related to teaching to improve the quality of professional training" ( UAN, 2017, p. 3 ). And that they aim to "Contribute to the improvement of the quality of higher education by promoting the performance of teaching staff through collaborative and collegial work; with the purpose of strengthening the integral formation of the student and the development of their professional competences established in the study plans and programs" (Ibídem).

The academies, as the bodies responsible for teaching, managing and accompanying students within the learning units, have the ability to identify, through their members, how the study plan is carried out. Each academy has a coordinator, who organizes and monitors the work of the academy and represents it in the curricular design processes.

The sample of this study focuses on 17 registered academies belonging to the different areas of knowledge of the UAN, integrated into the 29 updated programs. This is because its members have undergone the design and development processes of study plans, where curricular innovation models have been manifested / declared as an institutional policy and have been translated into a set of strategies for their implementation.

In the specific case of the academies, the coordinators have been selected, who organize the work within them, in addition to the fact that their activities are consistent with what is intended in this research. Likewise, the experience and perspective of the agents who have coordinated the updating processes at the institutional level (academics with a managerial or administrative position) are incorporated.

In the following section, some results of the opinions of university academics participating in this research as agents of curricular innovation are presented, taking up Bourdieu's theoretical premises and their implications in this process.

\footnotetext{
1 Permanent collegiate body, which belongs to each Academic Program whose objective is to design, update, modify and evaluate the curricular project (UAN, 2017, p.1).

\section{University academics as agents of curriculum innovation}

Bourdieu (2009b) in his work Homo Academicus, establishes that although the faculties of higher education centers can be treated and understood in a homogeneous way because agents with objective disciplinary relationships converge, in the same way there can be another level of analysis and understanding of the relationships between its members, where the competencies and positions regarding the occupation of the fields of power within the faculty make differences are established. Based on this theoretical approach, the opinions collected for the purpose of this work are analyzed.

The university field from Bourdieu's idea is defined "as a space of positions captured through the properties of agents who determine their attributes or attributions and who fight, with weapons and powers capable of producing visible effects, to take or defend them, to keep them intact or transform them "(2009b, p. 102).

In this university field it is important to understand that positions of power are given through the properties and capital of their occupants, that is, it is not the power of agent $\mathrm{X}$ of a faculty or school, it is the set of positions and recognitions It is the agents of that faculty or school that determine power and their capacity for determination (Bourdieu, 2009a).

This idea establishes a new way of understanding the power and determination relationships between the agents of the university fields: it is not about understanding the capacity of the academic as an individual agent, but the capacity of the academic as an agent of a group (call it the Academic Unit, Academic Program, Curricular Committee ${ }^{1}$ or Academy) and the role it plays as part of that group in the construction and determination of the curricular project. 
Like Bruner (2011) and Bourdieu $(2009 \mathrm{~b})$, it is recognized that one of the main characteristics of the academics who are part of the universities and centers of higher education is their ability to enter or not others into the body of academics; in other words, it is their ability to establish the rules of the game to occupy a position within the profession they wish to enter and, therefore, to determine whether the new professional will be empowered to exercise and play a role in the social fabric.

The idea that Bourdieu (2009b) and Brunner (2011) share is a clear reference to understand the curriculum committee as the group of agents that build a curriculum project for the training of other professionals. This project can be read as establishing the rules of the game to be part of a profession, as well as the canonical and disciplinary forms that must be followed in order to exercise.

In Bourdieu's (2009b) analysis of the distribution of power in the university, he establishes three situations that are important for understanding how university academics become agents of construction of a reality not given or determined by the political structure in turn.

A first situation is the conflict that is generated between new academics and those who already have a history in the institution for years, which is directly associated with a historical phenomenon that the author describes around the occupation of spaces of power and determination had always been separated by the age of the academics and by the years of experience they have in the university field, in such a way that the difference between new teachers and old teachers was clearly marked by biological questions that they became structural.

However, the arrival of new teachers with sufficient experience (scientific power) as a result of specialized postgraduates and who position them outside the age range and within the group of experts with disciplinary authority in the field, generates a conflict within the institutions.
In the field of study plan design and development, this conflict is observed in decision-making regarding the integration of disciplinary trends or the continuity of canonical knowledge constituting the profession, as well as in the number of participants in The curricular committees, that is, the attribute of being a member of a curricular committee (and in its case the coordinator of the academy) debates whether the degree of knowledge or experience in years within the exercise of the profession and teaching is privileged.

The conflict arises in determining the rules of the game of the profession. Academics newly incorporated into the university field, through academic training, do not always have knowledge of the practices and ways of exercising a profession in real contexts; On the other hand, older teachers know the rules of the profession and several have built them themselves, as a result of their experience and practice.

It is worth mentioning that, although the rules for the exercise of a professional practice in ancient times were given by high schools or by professional courts, today they have other names and forms of organization, such as professional associations, bars, associations and their certifications, up to those established by the state in the entrance and opposition exams (Consult Miguel Ángel Pasillas in University Teaching, 2011).

In the same sense, Bourdieu reveals in Homo Academicus, the existence of a university power and, on the other hand, the tradition and university patriotism. In this regard, the author establishes:

It is understandable that university power is so often independent of purely scientific capital and the recognition that it attracts. Temporal power in a universe that is neither de facto nor de jure consecrated to this kind of power, always tends to appear, perhaps even in the eyes of its most secure holders, as an inferior form of power, as a substitute, or as a consolation prize. It is also understood the deep ambivalence of the university students who dedicate themselves to the administration with respect to those who dedicate themselves, and successfully, to the investigation; especially in a university tradition in which university patriotism is weak and poorly rewarded (Bourdieu, 2009b, p. 134). 
The second situation related to the existence of a university power that is not based on scientific power, but on the relationships built by the agents and the ways in which they determine the very structure of life on the university campus and which, as the author, on many of these occasions this power is not perceived by the agents themselves, but acts in a structuring and structuring way (Bourdieu, 2009a) when participating in the innovation processes of the study plans.

Recognizing the existence of power in the agents that make curricular innovation possible or not, beyond the capital coming from the scientific field, makes us understand that they are capable of mobilizing within the curriculum field from their communication relationships with others and of their own conformation as university agents in addition to their capacity for empowerment in decision making.

The third situation generated from the construction of the discourse of the academic participants in the research is related to the existence of university tradition and patriotism, although the author refers to the ambivalent situation (and more of power distribution) between administrators and academics devoted to research, and how little reward is the commitment and loyalty to the institution.

In the context of the State Public Universities, a large number of the conditions to strengthen training, to recognize the trajectory, achieve a salary increase and even to access financial supports that impact the development of professional activities, are oriented for academic researchers; the academics dedicated to the administration do not have sufficient conditions for their professional development, however, the time they dedicate to their role is more than that agreed in the labor standards of the institutions, it is associated with a relationship of commitment and loyalty.

From the above, it is possible to affirm that the process of curriculum innovation at the UAN is crossed by this third situation in a structural way.
At the time of curricular design, academics with administrative functions are rarely invited to be part of the process of forming a new study plan, this gives preference to disciplinary experts and those who keep the trends of the profession up to date, in such a way Thus, the designs of the plans that incorporate curricular innovation do not always show consistency with the identity principles of the institution.

It is not meant that the academics dedicated to research do not maintain identity principles associated with the university, it is only pointed out the fact that the academics dedicated to the administration, as agents, possess a great capacity for decision making in the formation of plans. for study and for the training of new professionals.

\section{Conclusions}

When curricular innovation is developed in public universities, academic participation is conditioned by a collective habitus determined by the structure, which is associated with various elements of the public university.

The above means that it will have a position at the time it develops the curriculum innovation process, it will have previous precepts of the structure, but also of the new elements or positions of what it will assume as innovation.

At the time of developing the study plans and the curricular innovations that were integrated into them, the administrative conditions for their development do not always exist, here the academic administrators become a key piece and face two scenarios in which they have to choose ( enable, in Mollis terms) to build the conditions that were not planned so that the innovation can be developed or deny the need to change forms, procedures and elements of the current structure for the development of innovation. 
The choice of administrative academics is not the only condition for the development of curricular innovation, but it does show how in the decisions and participations of agents in the construction of the university curriculum it is the product of a structure, of a set of relationships, of power capacities, of collective positions, of agency capacities, of institutional commitments, of identity ties, of contextual conditions, which end up reflecting the strength of habitus in curricular innovation.

\section{References}

Acosta, S. (2008). La autonomía universitaria en América Latina: Problemas, desafíos y temas capitales. Universidades, LVIII (36), pp.69-82. Recuperado de http://www.redalyc.org/articulo.oa?id=3731290 9009.

Acosta, S. (2000). Estado, políticas y universidades en un periodo de transición. México: UDG-Fondo de Cultura Económica.

Aedo, A. (2014). El habitus y la movilidad social: de la modificación del sistema de disposiciones a la transformación de la estructura de clases. Revista de Sociología. Recuperado de http://www.revistadesociologia.uchile.cl/index. php/RDS/article/viewFile/36178/37851

Aguerrondo, I. (1992). La innovación educativa en América Latina: balance de cuatro décadas. Perspectivas, XXII (3), 381-394. Recuperado de http://unesdoc.unesco.org/images/0009/000950/ 095087so.pdf

Asociación Nacional de Universidades e Instituciones de Educación Superior (2000). La educación superior en el siglo XXI. Líneas estratégicas de desarrollo. Recuperado de http://publicaciones.anuies.mx/pdfs/revista/Rev ista113_S5A2ES.pdf

Blanco, G. y Messina, R. (2000). Estado del arte sobre las innovaciones educativas en América Latina. Recuperado de http://www.observatorioeducativo.pe/wpcontent/uploads/2013/11/ESTADO-DELARTE-SOBRE-LAS-INNOVACIONESEDUCATIVAS-EN-AM\%C3\%89RICALATINA.pdf

Bourdieu, P. (1980-2009). El sentido práctico. México: Siglo XXI editores.
Brunner, J. (2014). La idea de la Universidad pública en América Latina: Narraciones en escenarios divergentes. Educación XX1, 17 (2), 17-34. doi: 10.5944/educxx1.17.2.11477

Brunner, J. (2005). Transformaciones de la universidad pública. Revista de Sociología, No 19, 31-49. Recuperado de http://www.facso.uchile.cl/publicaciones/sociol ogia/articulos/19/1902-Brunner.pdf

Corvalán O. y Montero P. (2013). Seguimiento y contexto de proyectos de innovación curricular en entornos de políticas de educación superior. En O. Corvalán, J. Tardif y P. Montero (Coords), Metodologías para la innovación curricular universitaria basada en el desarrollo de competencias (pp.259-276). México: ANUIES.

De Alba, A. (2010). Currículum-sociedad. El peso de la incertidumbre, la fuerza de la imaginación. México: IISUE UNAM.

De Alba, A. (2007). Currículum-sociedad. El peso de la incertidumbre, la fuerza de la imaginación. México: IISUE.

De Alba, A. (1991). Currículum: crisis, mito y perspectivas. México, DF: UNAM.

De Alba, A. (1991). Evaluación curricular. Conformación conceptual del campo. México, DF: UNAM.

De Ibarrola, M. (2012). Experiencias y reflexiones sobre el diseño y la evaluación curricular. En M. Landesmann (Coord.), El currículum en la globalización A tres décadas del currículum pensado y el currículum vivido (pp.15-22). México: UNAM.

Díaz Barriga Arceo, Frida; Hernández Rojas, Gerardo; Bustos Sánchez, Alfonso (s.F.) (2 de mayo de 2018). Innovación Curricular en Entornos B-Learning mediante el desarrollo de Proyectos Colaborativos con estudiantes universitarios. $\mathrm{X}$ Congreso Nacional de Investigación Educativa. México

Díaz Barriga, A. (2015). Currículum: entre utopía y realidad. Argentina: Amorrortu editores. 
Díaz Barriga, A. y García, G. J. (2014). Desarrollo del currículum en América Latina. Lo que aprendimos. En A. Díaz-Barriga \& J. García (coords.), Desarrollo del currículum en América Latina. Recuperado de file:///C:/Users/Jazm\%C3\%ADn\%20PC/Downl oads/Desarrollo\%20del\%20curriculum\%20en $\%$ 20Am\%C3\%A9rica\%20Latina_imprenta(15)\% 20Copy.pdf

Díaz Barriga, A. F. (2013). Innovaciones curriculares. En A. Díaz Barriga. (coord.), La investigación curricular en México 2002-2011, (109-179). México: ANUIES, COMIES.

Díaz-Barriga A. F. (2010). Los profesores ante las innovaciones curriculares. Revista Iberoamericana de Educación Superior [en línea] I (junio-septiembre): Recuperado de http://www.redalyc.org/articulo.oa?id=2991285 87005

Díaz Barriga, A. F. (2005). Desarrollo del currículo e innovación: modelos e investigación en los noventa. Perfiles Educativos (Online). Vol. 27, n.107, pp. 57-84. ISSN 0185-2698.

Díaz, M., y Nieto, L.M. (2012). Del concepto de innovación. Contextos, 1(4), 39-53.

Díaz-Villa, M. (2011). Los discursos sobre la flexibilidad y las competencias en la educación superior. Pedagogía y saberes, No 35, p-24. Recuperado http://revistas.pedagogica.edu.co/index php/PY S/article/viewFile/1051/1063

Díaz-Villa, M. (2013). Currículum: debates actuales. Trazos desde América Latina. Contextos, 2(8), 21-33. Recuperado de http://revistas.usc.edu.co/index.php/Contextos/a rticle/view/356\#.VlUa1nYvfIU

Furlan, M. (2012). El currículum pensado y el currículum vivido. En M. Landesmann. (coord.), El currículum en la globalización. A tres décadas de El currículum pensado y el currículum vivido (15-22). México, D.F: UNAM.

Gimeno, S. (2013). El currículum: una reflexión sobre la práctica. Madrid: Morata. (Año de publicación del libro original, 1988, 10ma edición).
Gimeno S. (2010). El currículum en la sociedad de la información y del conocimiento. En J. Gimeno Sacristán. (Comp.), Saberes e incertidumbres sobre el currículum (pp. 180202). Madrid: Morata.

González, B. \& Zea, V. (2011). Metodología para el diseño de proyectos curriculares por competencias profesionales integradas (documento de trabajo). Recuperado de http://www.uan.edu.mx/d/a/sd/dpe/_metod_dise no_proectos_curric_compet.pdf

Gros, S. y Lara, N. (2009). Estrategias de innovación en la educación superior. Recuperado de http://rieoei.org/rie49a09.pdf

Guevara, H. (2010). Integración tecnológica del profesor universitario desde la teoría social de Pierre Bourdieu. Revista de Innovación Educativa, Núm. especial. Recuperado de http://www.udgvirtual.udg.mx/apertura/index.p hp/apertura/article/view/133/136

Kemmis, S. (1988-1998). El currículum: más allá de la teoría de la reproducción. Madrid: Morata.

Martínez Lobatos, Lilia; Toledo Sarracino, David; Román Gálvez. Rey D. (s.F.) (2 de mayo de 2018). El currículo frente al pensamiento de la innovación. Un estudio en algunas carreras de Ingeniería. X Congreso Nacional de Investigación Educativa. México

Mota, M. (2013). El habitus internético escolar de estudiantes de la Universidad Autónoma de Aguascalientes. Tesis doctoral, Doctorado Interinstitucional en Educación. Guadalajara, México: ITESO.

Muñoz, G. H. (2015). Un apunte sobre las limitaciones impuestas a la autonomía universitaria. Perfiles Educativos, XLIV (4), número 176, 111-137. Recuperado de $\mathrm{http} / / /$ publicaciones.anuies.mx/pdfs/revista/Rev ista176_S3A5ES.pdf

Ospina Romero, A. (2006). (1 de mayo de 2018). Currículo por competencias en la

Rodríguez, G. R. (09 de abril de 2015). A 15 años del Plan ANUIES. Seminario de Educación Superior. Recuperado de http://www.ses.unam.mx/publicaciones/articulo s.php?proceso $=$ visualiza\&idart $=2094$ 
Ruiz, M. M. (2011). Políticas Públicas en Salud y su Impacto en el Seguro Popular en Culiacán, Sinaloa, México.

San Martín, D. y Quilaqueo, D. (2012). Habitus profesional y relaciones intersubjetivas entre profesores principiantes y experimentados. Perfiles Educativos, XXXIV (136), 63-78.

Sousa S. B. (2015). La universidad en el siglo XXI. México: Siglo XXI editores.

Stenhouse, L. (1984-2010). Investigación y desarrollo del curriculum. Madrid, Morata.

Torres, J. (2011). La justicia curricular. El caballo de Troya de la cultura escolar. España: Morata.

Torres, J. (2006). Globalización e interdisciplinariedad: el curriculum integrado. España: Morata (año de publicación del libro original, 1991; 5ta edición).

Torres, J. (2003). El curriculum oculto. Madrid, España: Morata (año de publicación del libro original, 1991, 7ma edición).

Treviño, E. (2015). La Educación Superior y el advenimiento de la sociedad del conocimiento. México: ANUIES.

Tunnermann, B. (2008). La autonomía universitaria en el contexto actual. Universidades LVIII (36), pp. 19-46. Recuperado de http://www.redalyc.org/pdf/373/37312909004.p df

UNESCO, (2005). Informe mundial de la UNESCO. Hacia las sociedades del conocimiento. Recuperado de http://unesdoc.unesco.org/images/0014/001419/ 141908s.pdf

Universidad Autónoma de Nayarit, (2018). 3er Informe de labores.

Universidad Autónoma de Nayarit. (2003).

Documento Rector. Recuperado de http://www.uan.edu.mx/d/a/sg/Legislacion/dcf4 .pdf

Universidad Autónoma de Nayarit. (2017). Lineamientos para la integración y operación de los Comités Curriculares de la Universidad Autónoma de Nayarit.
Universidad Autónoma de Nayarit. (2017). Lineamientos para la conformación y operación y evaluación de las academias de programas de nivel de profesional asociado y licenciatura de la Universidad Autónoma de Nayarit.
VERDÍN-ZEA, Aldo A., ABUNDIS-DE LEÓN, Felipe and GONZALEZ-BASILIO, Sofía de Jesús. Educational innovation and university academics: the challenges of incorporating change into teaching and management practice. Journal of Human Resources Training. 2020 